\title{
The effect of drying and partial neutralization of grass silage on voluntary intake by sheep
}

\author{
RIITTA SORMUNEN-CRISTIAN
}

\begin{abstract}
SORMUNEN-Cristian, R. 1992. The effect of drying and partial neutralization of grass silage on voluntary intake by sheep. Agric. Sci. Finl. 1: 189-194. (Agric. Res. Centre of Finland, Inst. Anim. Prod., SF-31600 Jokioinen, Finland.)
\end{abstract}

\begin{abstract}
The experiment was carried out to provide information on the effect of drying and partial neutralization of direct cut grass silages on voluntary intake by sheep. It was designed as a $4 \times 4$ latin square comparison of four dietary treatments with four castrated Finnish Landrace rams. The DM content of the dried silage was $81.6 \%$. There were two levels of neutralization in the experiment: either 8 or $16 \mathrm{~g}$ of sodium bicarbonate $\left(\mathrm{NaHCO}_{3}\right)$ was mixed with the silages. The lower level of neutralization raised the silage $\mathrm{pH}$ from 3.95 to 4.36 and the higher level took it up to 5.57 . Both the drying of silage and the addition of $16 \mathrm{~g}$ of $\mathrm{NaHCO}_{3}$ produced a significant $(\mathrm{P}<0.05)$ increase in the DM intake by sheep. The average daily intake for animals on dried silage was 71.4 $\mathrm{g} \mathrm{DM} / \mathrm{kgW}^{0.75}$, on the $16 \mathrm{~g}$ neutralization level $62.7 \mathrm{~g} \mathrm{DM} / \mathrm{kgW}^{0.75}$, on the $8 \mathrm{~g}$ neutralization level $53.4 \mathrm{~g} \mathrm{DM} / \mathrm{kgW}^{0.75}$ and on untreated silage $52.4 \mathrm{~g} \mathrm{DM} / \mathrm{kgW}^{0.75}$. The sheep offered dried silage gained a significantly $(\mathrm{P}<0.05)$ larger amount of protein and energy than those on the other silage diets. The animals offered dried silage consumed $2.4 \mathrm{~kg}$ of water/DM kg daily and those offered untreated silage $0.7 \mathrm{~kg}$.
\end{abstract}

Key words: sodium bicarbonate, drying, silage intake, sheep

\section{Introduction}

Grass silage is - in addition to hay - an important roughage for sheep during the indoor feeding period. Since the feed unit price of silage is lower than that of hay (HELANDER 1991), the utilization of silage should be increased in order to reduce feeding costs in meat production. Silage is acceptable for feeding of pregnant and lactating ewes (APOLANT and CHESTNUTT 1985), whereas weaned lambs at the age of 2-5 months have been found to grow better when fed on hay rather than on silage made from the same sward (SORMUNEN-CRISTIAN 1984). Lambs fed ad libitum with only grass silage have even been found to lose weight (SAUE 1968).
Insufficient voluntary intake of silage by sheep is known to limit their growth rate as compared with hay. Some of the primary factors considered to reduce the voluntary intake of ensiled forages include, e.g., high moisture content (WILKINS et al. 1971), low silage pH (SHAVER et al. 1985) as well as high contents of shortchain fatty acids (WILKINS et al. 1971) and lactid acid (MCLeOD et al. 1970). However, the low dry matter (DM) content of the forage has not always reduced the feed intake (BULL and TAMPLIN 1974).

The dry matter intake of silage has been found to increase along with an increase in its dry matter content (MERCHEN et al. 1986). The effect of DM content on the voluntary intake of silage has pri- 
marily been studied with prewilted silages. On the other hand, the effect of silage drying on palatability has not been studied much.

Sodium bicarbonate has been used as an additive in silage-based diets to offset the deleterious nutritional effects of low ruminal $\mathrm{pH}$. Partial neutralization of silage acidity with sodium bicarbonate has been found to increase feed intake in many studies (ERdman et al. 1980, KiLmer et al. 1980, Shavier et al. 1985). However, sodium bicarbonate has not improved feed intake under all conditions. Findings have differed depending on animal species and on the way sodium bicarbonate was added and on the amounts added (FARHAN and THOMAS 1978). The objective of this study was to compare the voluntary intake by sheep fed direct cut, dried silage and silage treated with sodium bicarbonate.

\section{Material and methods}

Four castrated rams of Finnish Landrace breed, aged 6.0 years (S.D. 0.02) with an average initial weight of $93.2 \mathrm{~kg}$ (S.D. 4.22) were allocated into four groups fed either direct cut silage (silage 1), dried silage (silage 2), and fresh silage neutralized with sodium bicarbonate $\left(\mathrm{NaCHO}_{3}\right)$ at a level of 8 $\mathrm{g}$ (silage 3 ) or $16 \mathrm{~g}$ (silage 4) per $\mathrm{kg}$, respectively. The silages were offered ad libitum at $15 \%$ refusal levels. Feed and water intakes were recorded daily throughout the experiment period of 12 weeks. The silages had been made simultaneously before mid June from similar herbage containing timothy (49 $\%$ ) and meadow fescue (43\%). AIV II containing $80 \%$ formic acid and $2 \%$ phosphoric acid was used as an additive $(5 \mathrm{l} / \mathrm{t})$. Silage 2 was packed into gunny-sacks of $10 \mathrm{~kg}$ each, and artificially dried in a warm air dryer at $20-30^{\circ} \mathrm{C}$ for 48 hours before feeding. The purpose of drying the silage was to find out how much the feed intake increases when the dry matter content of silage is equal to that of hay. Sodium bicarbonate was mixed with silages 3 and 4 manually immediately prior to feeding.

The samples of silages were analyzed for dry matter (Huida et al. 1986), pH, total and water soluble nitrogen by the Kjeldahl method, ammo- nium nitrogen (MCCUlLOUGH 1967), lactic acid (BARKER and SUMMERSON 1941), volatile fatty acid by gas chromatography (HUIDA 1973) as well as for water-soluble carbohydrates (WSC) (SomOGYI 1945) and ethanol (HuIDA 1982). In vivo digestibility of untreated silage was determined by the total collection method with the wethers. It was assumed that digestibility did not differ significantly between the treatments (HAwKIns et al. 1970, FARHAN and Thomas 1978, Phillip 1983).

The experiment was designed as a $4 \times 4$ latin square comparison. The results were subjected to an analysis of variance. The differences between the treatments were tested using Tukey's test (STEEl and TORrie 1969).

\section{Results and discussion}

The chemical composition and feed value of the silages are shown in Table 1. In the experiment, the DM content of dried silage was about $81.6 \%$ compared to $21-22 \%$ in fresh and neutralized forages. The silages were made at an early stage of grass growth and thus had a very low crude fibre content, only $22-24 \%$ of DM, and a high crude protein content ( $\mathrm{N} \times 6.25), 21-24 \%$ of DM on an average. The protein content of the dried silage was significantly $(\mathrm{P}<0.05)$ higher than that of the other forages. As expected, forage organic matter $(\mathrm{OM})$ content was at its lowest in the neutralized silages. Ash content was increased significantly $(\mathrm{P}<0.05)$ by the higher level of sodium bicarbonate addition.

The quality of each silage was deemed to be good (BREIREM and Номв 1970). The extent of fermentation is indicated by the low silage $\mathrm{pH}$ of 3.95 . The neutralization of silage 3 with $8 \mathrm{~g}$ sodium bicarbonate raised the $\mathrm{pH}$ to 4.36 and neutralization with 16 $\mathrm{g}$ to $5.57(\mathrm{P}<0.05)$. Because the sodium bicarbonate was added to the silages just before feeding, the silage fermentation was not altered. Ammonium nitrogen accounted for $3.6-4.7 \%$ of the total nitrogen. No butyric acids were encountered in the forages. The dried silage contained significantly $(\mathrm{P}<0.05)$ less acetic acid than the other silages. Drying reduced the volatile fatty acids in the silage 
Table 1. Average chemical composition and feed value of silages during the feeding experiment.

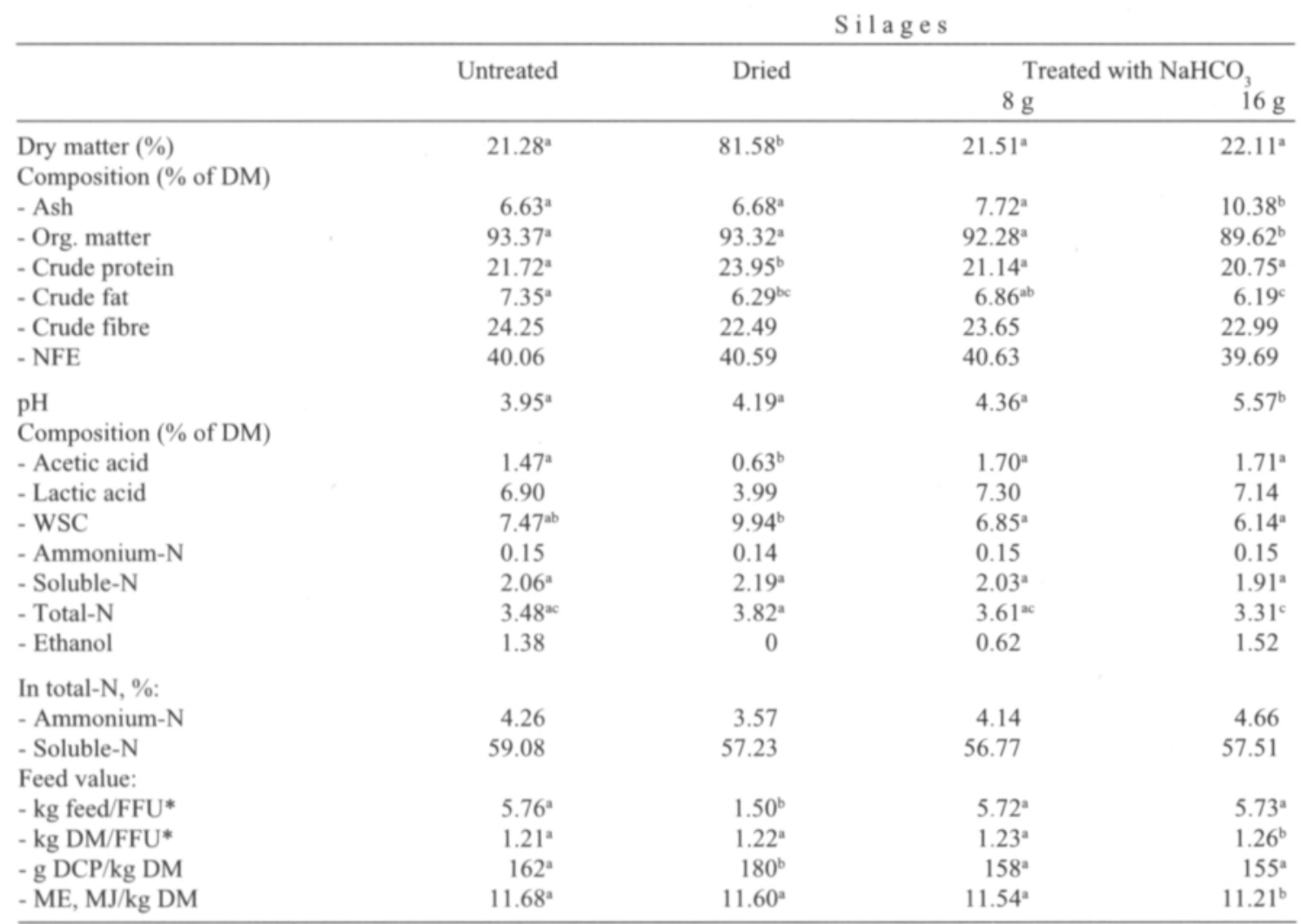

Means with different supercripts are significantly different $(\mathrm{P}<0.05)$.

${ }^{*} \mathrm{FFU}=\mathrm{NK}_{\mathrm{F}}, \mathrm{MJ} / 6.91 \mathrm{MJ}$

by $60 \%$ approximately. The average amount of lactic acid in the dried silage was $4.0 \%$ of the DM, whereas the figures were $6.9,7.3$ and $7.1 \%$ for the untreated and neutralized silages, respectively. However, the differences between the silages were not statistically significant $(\mathrm{P}>0.05)$. The lactic acid content of the dried silage was almost the same before and after drying.

There were distinct differences in the voluntary intakes of the different silages (Table 2). Both the drying of silage and its partial neutralization with sodium bicarbonate increased the DM intake by the sheep. The most favoured was dried silage with an average DM intake of $2.29 \mathrm{~kg}\left(71.4 \mathrm{~g} \mathrm{DM} / \mathrm{kgW}^{0.75}\right)$ per day during a period of 12 weeks. The sheep had the lowest appetite for fresh, untreated silage, the average daily intake being only $1.65 \mathrm{~kg}(52.4 \mathrm{~g}$ $\mathrm{DM} / \mathrm{kgW}^{0.75}$ ). Adding $16 \mathrm{~g}$ of $\mathrm{NaHCO}_{3}$ increased the intake more than the addition of $8 \mathrm{~g}$ of $\mathrm{NaHCO}_{3}$. At the lower level of neutralization, the average DM intake was $1.70 \mathrm{~kg}(53.4 \mathrm{~g} \mathrm{DM} /$ $\left.\mathrm{kgW}^{0.75}\right)$ and at the higher level $1.98 \mathrm{~kg}(62.7 \mathrm{~g}$ $\mathrm{DM} / \mathrm{kgW}^{0.75}$ ). The $\mathrm{DM}$ intakes in the different silage groups differed significantly $(\mathrm{P}<0.05)$, with the exception of silages 1 (untreated) and 3 ( $8 \mathrm{~g}$ $\mathrm{NaHCO}_{3}$ ). In the study by PHILlip (1983), the voluntary intake of dry matter and organic matter was enhanced by the addition of sodium bicarbonate, but the effect was not statistically significant $(\mathrm{P}>0.10)$. When silage $\mathrm{pH}$ increased from 3.95 to 5.57 with $16 \mathrm{~g} \mathrm{NaHCO}_{3}$, the organic matter intake increased by $0.23 \mathrm{~kg} / \mathrm{day}$. The organic matter 
Table 2. The effect of drying and partial neutralization on the intake of silage and water (animal/day).

\begin{tabular}{lrrrr} 
& \multicolumn{3}{c}{ S i l a g e s } \\
\hline Untreated & Dried & $\begin{array}{r}\text { Low level } \\
\text { NaHCO }_{3}\end{array}$ & $\begin{array}{r}\text { High level } \\
\text { NaHCO }_{3}\end{array}$ \\
\hline DM intake, g & $1686^{\mathrm{c}}$ & $2309^{\mathrm{a}}$ & $1720^{\mathrm{c}}$ & $2004^{\mathrm{b}}$ \\
- Silage & $1654^{\mathrm{c}}$ & $2286^{\mathrm{a}}$ & $1697^{\mathrm{c}}$ & $1984^{\mathrm{b}}$ \\
- Salt & 25 & 20 & 20 & 15 \\
- Minerals & 7 & 3 & 3 & 5 \\
OM intake, g & & & $1565^{\text {cd }}$ & $1776^{\mathrm{bc}}$ \\
DOM intake, & $1542^{\mathrm{d}}$ & $2134^{\mathrm{a}}$ & $1235^{\mathrm{cd}}$ & $1401^{\mathrm{bc}}$ \\
CP intake, g & $1214^{\mathrm{d}}$ & $1658^{\mathrm{a}}$ & $360^{\mathrm{b}}$ & $411^{\mathrm{b}}$ \\
DCP intake, g & $362^{\mathrm{b}}$ & $548^{\mathrm{a}}$ & $270^{\mathrm{b}}$ & $308^{\mathrm{b}}$ \\
NE, FFU* & $272^{\mathrm{b}}$ & $411^{\mathrm{a}}$ & $1.38^{\mathrm{b}}$ & $1.57^{\mathrm{b}}$ \\
ME, MJ & $1.36^{\mathrm{b}}$ & $1.87^{\mathrm{a}}$ & $19.58^{\mathrm{b}}$ & $22.21^{\mathrm{b}}$ \\
Water intake, g & $19.29^{\mathrm{b}}$ & $26.52^{\mathrm{a}}$ & $2035^{\mathrm{b}}$ & $2226^{\mathrm{b}}$ \\
Water intake, gDM kg & $1158^{\mathrm{b}}$ & $5552^{\mathrm{a}}$ & $1214^{\mathrm{b}}$ & $1129^{\mathrm{b}}$ \\
\hline
\end{tabular}

Means with different supercripts are significantly different $(\mathrm{P}<0.05)$.

* $\mathrm{FFU}=\mathrm{NK}_{\mathrm{F}}, \mathrm{MJ} / 6.91 \mathrm{MJ}$

intake on dried silage was significantly $(\mathrm{P}<0.05)$ higher than that on the other diets.

Drying of silage increased the DM intake by 37 $\%$. This finding differs from the results of the study conducted by BULL and TAMPLIN (1974), according to which the drying of maize silage either decreased the consumption or had no effect on the appetite. On the other hand, the DM intake of prewilted silage $(80.0 \% \mathrm{DM})$ by sheep has been found to be nearly $29 \%$ higher than their intake of fresh silage (22.5\% DM) (HawKINS et al. 1970). WILKINS et al. (1971) have found that the nitrogen content of silage correlates positively and acetic acid content negatively with intake. It was assumed also in this study that the high protein and low acetic acid content of the dried silage would have a positive effect on the dry matter intake.

The partial neutralization of silage acidity with sodium bicarbonate has increased intake according to many reports (MCLEOD et al., ERDMAN et al. 1980, Phillip 1983, Shaver et al. 1985), but there are exceptions (LANCESTER and WILSON 1975, FARHAN and THOMAS 1978). In this study, the hig- her addition of $\mathrm{NaCHO}_{3}$ increased the $\mathrm{DM}$ intake by $20 \%$ and the lower by $4 \%$. The average response to raising the silage $\mathrm{pH}$ above 5 has been an increase of intake by $14.9 \%$ with sheep (FARHAN and THOMAs 1978, LANCASTER and WiLSON 1975, MCLEOD et al. 1970). When sodium bicarbonate was infused straight into the rumen, its effect was found to be greater than when it was fed with silage (FARHAN and ThOMAs 1978). Since $\mathrm{NaHCO}_{3}$ has also improved the hay DM intake (ORTH and KAUFMANN 1966), its effect has not always been linked with silage acidity.

Intake of organic matter was about $15 \%$ higher for the animals receiving silage neutralized with 16 $\mathrm{g}$ bicarbonate than for those receiving the control treatment. The differences were not, however, statistically significant $(\mathrm{P}>0.05)$. FARHAN and THOMAS (1978) found that bicarbonate addition to the feed increased the sheep's OM intake by about $5 \%$.

Individual differences in DM intake by the animals were pronounced. Differences in the intakes of the same silage varied between $0.15-0.50 \mathrm{~kg}$, the largest differences being with untreated silage and 
the smallest with the $16 \mathrm{~g}$ neutralization level. An animal consuming an average of $68 \mathrm{~g} \mathrm{DM} / \mathrm{kgW}^{0.75}$ daily gained $236 \mathrm{~g}$ per day during the period of 12 weeks, while the average weight gain of the others was $167 \mathrm{~g}$ per day.

The animals fed on dried silage gained significantly more $(\mathrm{P}<0.05)$ protein and energy than those on the other silage diets. Through the mere addition of $\mathrm{NaHCO}_{3}$, the animals acquired an average amount of $17 \mathrm{~g}$ and $39 \mathrm{~g}$ of sodium per day. Sodium was also obtained from the silages themselves, minerals and salt. The effect of $\mathrm{NaHCO}_{3}$ on salt and mineral intakes was small.

The amount of sodium gained from neutralized silages surpassed manifold the sodium requirement of sheep. The need for sodium according to the nutrient requirement varies depending on the production stage of the animal from 1 to 4 grams daily (NRC 1985). Despite the great excess of sodium, no health problems were encountered with the sheep. However, when applying these findings to the feeding of growing lambs, attention should be paid to the fact that the wethers were held on each of these silage diets for three weeks only.
The treatments were associated with a marked increase in water intake (Table 2). The sheep offered dried silage consumed almost five times more water than those on untreated diets, $5.5 \mathrm{~kg}$ per day on an average. At its highest, the water consumption was $10.0 \mathrm{~kg}$ per day. Water intake on dried silage was significantly $(\mathrm{P}<0.05)$ higher than on the other diets. Water intake has been found to have a strong positive correlation with dry matter intake (HADJIPANAYIOTOU 1981).

Neutralization increased the average water intake by 1 kilo. The lower level of neutralization increased water intake by $76 \%$ and the higher by 92 $\%$. The bigger water intake reflects the higher $\mathrm{Na}$ content in the neutralized diets. On diets supplemented with $4 \% \mathrm{NaHCO}_{3}$ water consumption has been found to increase by 16-25\% (HADJIPANAYIOTOU 1981). Drying increased water intake/DM kg significantly $(\mathrm{P}<0.05)$.

The dried silage and silage neutralized with sodium bicarbonate proved to be acceptable to the animals. The addition of sodium bicarbonate to the feed appeared to be advantageous when the diet contained a high proportion of acid silage.

\section{References}

APOlant, S.M. \& Chestnutt, M.B. 1985. The effect of mechanical treatment of silage on intake and production of sheep. Anim. Prod. 40: 287-296.

BARKER, S.B. \& Summerson, W.H. 1941. The colorimetric determination of lactic acid in biological material. J. Biol. Chem. 138: 535-553.

Breirem, K. \& Номв, T. 1970. Förmidler og förkonservering. Buskap og Avdrått A/S, Gjøvik. 459 p.

BuLl, L.S. \& TAMPLIN, C.B. 1974. Effect of moisture on intake in sheep. J. Anim. Sci. 39: 234 (Abstr.).

Erdman, R.A., Botts, R.L., Hemken, R.W, \& Bull, L.S. 1980. Effect of dietary sodium bicarbonate and magnesium oxide on production and physiology in early lactation. J. Dairy Sci. 63: 923-930.

Farhan, S.M.A. \& Thomas, P.C. 1978. The effect of partial neutralization of formic acid silage with sodium bicarbonate on their voluntary intake by cattle and sheep. J. British Grssl. Soc. 33: 151-158.

HADIIPANAYIOTOU, M. 1982. Effect of sodium bicarbonate and of roughage on milk yield and milk composition of goats and on rumen fermentation of sheep. J. Dairy Sci. 19: 59-64.

Hawkins, D.R., Henderson, H.E. \& Purser, D.B. 1970. Effect of dry matter levels of alfalfa silage on intake and metabolism in the ruminant. J. Anim. Sci. 31: 617-625.

HELANDER, J. 1991. HILA:n, T-tarkkailun ja MATU:n tuloksia. Maaseutukeskusten liitto. Helsinki. Mimeogr. 23 p.

HUIDA, L. 1973. Haihtuvien rasvahappojen kvantitatiivinen määrittäminen pötsinesteestä ja säilörehusta kaasunestekromatografisesti. J. Sci. Agric. Soc. Finland 45: 483488.

- 1982. Gas chromatographic determination of water and ethanol in silage by internal standard method. J. Sci. Agric. Soc. Finland 54: 137-143.

—, VÄĂTÄINEN, H. \& LAMPILA, M. 1986. Comparison of dry matter contents in grass silages as determined by oven drying and gas chromatographic water analysis. Ann. Agric. Fenn. 25: 215-230. 
Kilmer, L.H., Mứler, L.D. \& Wangsness, P.J. 1980. Addition of sodium bicarbonate to rations of pre and post partum dairy cows. J. Dairy Sci. 63: 2026-2036.

LANCASTER, J.R. \& Wilson, P.K. 1975. Effect on intake of adding sodium bicarbonate to silage. New Zealand Journal of Experimental Agriculture 3: 203-206.

McCullough, H. 1967. The determination of ammonia in whole blood by a direct colorimetric method. Clin. Chim. Acta 17: 297-304.

MCLeOD, D.S., WILKInS, R.J. \& RaYMOND, W.F. 1970. The voluntary intake by sheep and cattle of silage differing in free-acid content. J. Agric. Sci., Camb. 75: 311-319.

Merchen, N.R., Berger, L.L. \& Fahey, G.G. 1986. Comparison of the effects of three methods of harvesting and storing alfalfa on nutrient digestibility by lambs and feedlot performance of steers. J. Anim. Sci. 63: 10261035.

NRC. 1985. Nutrient requirements of domestic animals. Nutrient requirements of sheep. National Research Council. 99 p. 6th ed. Washington.

ORTH, A.\& KaufmanN, M. 1966. Zur Wirkung von Bicarbonat auf die Futteraufnahme bei Milchkühen. Zeitschrift für Tierenährung und Futtermittelkunde 21: 350-361.

PHILLIP, L.E. 1983. Effect of sodium bicarbonate on nitrogen utilization and feed intake by lambs. Can. J. Anim. Sci. 63: 613-621.

SAUE, O. 1968. The effect of different methods of grass, con- servation on voluntary feed intake, body weight gains and feed expenditures in lambs. Inst. Anim. Nutr. Agr. Coll. Norway. Tech. Bull. 135.

Shaver, R.D., ERdman, R.A., O'CONNOR, A.M. \& VANDERSALL, J.H. 1985. Effects of silage pH on voluntary intake of corn silage and alfalfa haylage. J. Dairy Sci. 68: 338346 .

SomoGYI, M. 1945. A new reagent for the determination of sugars. Determination of blood sugar. J. Biol. Chem. 160: 61-73.

SORMUNEn-Cristian, R. 1984. Hay and silage as forage for sheep. NJF's seminarium nr 59 "Fårens utfodring och skötsel under vinterperioden", Tune, Denmark.

Steel, R. \& Torrie, J. H. 1960. Principles and procedures of statistics. McGraw-Hill Book Company. 481 p. New York.

Wilkins, R.J., Hutchinson, K.J., WILsON, R.F. \& HaRRIS, C.E. 1971. The voluntary intake of silage by sheep. 1 . Interrelationships between silage composition and intake. J. Agric. Sci., Camb. 77: 531-537.

\section{Manuscript received February 1992}

Riitta Sormunen-Cristian

Agricultural Research Centre of Finland

Institute of Animal Production

SF-31600 Jokioinen, Finland

\title{
SELOSTUS
}

\section{Kuivauksen ja neutraloinnin vaikutus säilörehun maittavuuteen lampailla}

\author{
RIITTA SORMUNEN-CRISTIAN \\ Maatalouden tutkimuskeskus
}

Tutkimuksessa selvitettiin säilörehun neutraloinnin ja kuivauksen vaikutusta säilörehun syöntiin lampailla. Tutkimus tehtiin neljällä kastroidulla pässillä 4 x 4 latinalaisen neliön mukaan. Kuivatun säilörehun kuiva-ainepitoisuus oli 81,6 \%. Neutralointitasoja oli kaksi. Säilörehuun lisättiin joko $8 \mathrm{~g}$ tai $16 \mathrm{~g}$ natriumbikarbonaattia $\left(\mathrm{NaHCO}_{3}\right)$ rehukiloa kohti. Alempi neutralointitaso nosti säilörehun pH:n 3,95:stä 4,36:een ja korkeampi taso 5,57:ään. Sekä säilörehun kuivaaminen että 16 gramman $\mathrm{NaHCO}_{3}$-määrä lisäsivät merkit- sevästi $(\mathrm{P}<0,05)$ kuiva-aineen syöntiä lampailla. Keskimääräinen syönti kuivatulla säilörehulla oli $71,4 \mathrm{~g} \mathrm{ka} / \mathrm{kgW}^{0,75}, 16$ gramman neutralointitasolla $62,7 \mathrm{~g} \mathrm{ka} / \mathrm{kgW}^{0,75}, 8$ gramman neutralointitasolla $53,4 \mathrm{~g} \mathrm{ka} / \mathrm{kgW}^{0,75}$ ja käsittelemättömällă säilörehulla $52,4 \mathrm{~g} \mathrm{ka} / \mathrm{kgW}^{0,75}$. Kuivatulla säilörehulla lampaat saivat merkitsevästi $(\mathrm{P}<0,05)$ enemmän sekä valkuaista että energiaa kuin muilla rehuilla. Syötyä rehun kuiva-ainekiloa kohti keskimääräinen vedenjuonti oli kuivalla rehulla $2,4 \mathrm{~kg}$ ja käsittelemättömällä rehulla $0,7 \mathrm{~kg}$. 